\title{
Predictors of the Desire/Decision to Quit Smoking in a Cohort of Croatian Adult Smokers Followed for Five Years: The CroHort Study
}

\author{
Marta Čivljak ${ }^{1}$, Milan Miloševiéc ${ }^{1}$ Ivan Ćelić ${ }^{2}$, Tea Vukušić Rukavina ${ }^{1}$, Ognjen Brborović ${ }^{1}$ and \\ Stipe Orešković ${ }^{1}$ \\ ${ }^{1}$ University of Zagreb, School of Medicine, »Andrija Štampar« School of Public Health, Zagreb, Croatia \\ ${ }^{2}$ Vrapče Clinic for Psychiatry, Zagreb, Croatia
}

\begin{abstract}
A B S T R A C T
This study provides an overview of the incidence of smoking, the socio-demographic characteristics of Croatian smokers during a five-year period and an assessment of predictors of the desire/decision to quit smoking. Analyses were performed separately for 2003 and 2008. A total of 3,229 subjects were included in the survey. There is a significant trend of a decreasing number of smokers in all age groups in 2008, compared to 2003. Almost half of the smokers included in the study expressed desire to quit smoking. Factors contributing significantly to decision to quit smoking were different in 2003 and 2008, except one. Concern about the harmful effects of tobacco smoking on health was a significant predictor in both models. Very worried respondents were more likely to decide to quit smoking (OR 17.6, 95\% CI 9.41 to 33.17 vs. OR 12.54; 95\% CI 6.0 to 26.2) than those who were not worried at all.
\end{abstract}

Keywords: smoking cessation, smoking cessation predictors, smoking cessation interventions, CroHort study

\section{Introduction}

It is well known that most smokers feel that tobacco is harmful and want to quit smoking ${ }^{1}$. There is evidence that although $70 \%$ of US smokers say they want to quit, only five percent are able to sustain cessation for one year ${ }^{2}$.

Tobacco addiction is a chronic condition. Smokers often use multiple smoking cessation interventions or the same intervention several times in order to abstain successfully from smoking. Nicotine is highly addictive ${ }^{3}$. The pharmacological and behavioral processes that determine nicotine addiction are similar to those that determine addiction to other drugs ${ }^{3}$.

The benefits of smoking cessation are extremely high. In addition to reducing the risk of smoking-related diseases, it slows the progression of already developed diseases and prolongs life expectancy. Life expectancy among smokers who quit at age 35 exceeded that of continuing smokers by an average of 7 years. Stopping smoking as early as possible is important but cessation at any age provides meaningful life extension. Therefore, even those who quit much later in life (65 years of age) gain some benefits: life extension by an average of 2 years ${ }^{4}$. The balance between an individual's motivation to stop smoking and his or her dependence on cigarettes influences smoking cessation success ${ }^{5-7}$. The transtheoretical model posits that health behavior change involves progress through six stages of change: precontemplation, contemplation, preparation, action, maintenance and termination. Ten processes of change have been identified for producing progress along with decisional balance, self-efficacy and temptations $\mathrm{s}^{8-10}$. Despite an individual's motivation to stop smoking and his/her nicotine addiction, a range of predictors and moderators influence smoking cessation success. There is evidence that being a female, college educated and having a supportive partner are important predictors of successful smoking cessation ${ }^{11-14}$. Brief advice from doctor's helps smokers quit, especially if it is part of more intensive interventions ${ }^{15}$. The environment in which a smoker lives or works has a very large impact on the success of smoking cessation. A large number of studies have proved that a ban on smoking at work is a significant predictor of successful smoking cessation ${ }^{16,17}$. 
Knowing the socio-demographic characteristics of smokers and the factors contributing to the prediction of the desire to quit smoking might be useful in the development of effective public health smoking cessation interventions. Interventions that are tailored to the needs and other characteristics of smokers are more effective ${ }^{18}$. Therefore, this article provides an overview of the incidence of smoking, the socio-demographic characteristics of Croatian smokers in 2003 and 2008, and an assessment of the predictors of the desire/decision to quit smoking.

\section{Methods}

The sample of this study consisted of 3,229 respondents (1,015 male and 2,214 female) who participated in both the Croatian Adult Health Survey 2003 and the follow-up Croatian Adult Health Survey 2008. All were 18 years or older at the time of the first survey. Further details on this sample have been described elsewhere ${ }^{19}$. Interviews were conducted by trained interviewers - public health nurses. One of the questions in the survey was the following: "When did you last smoke? « Those who responded yesterday or today, two days ago to a month, a month ago to six months were defined as smokers. We decided to define nonsmokers as those who had not lit a single cigarette during the past six months because this outcome is one of the standard recommendations for most of the trials assessing the smoking habit. It is hoped that reporting six-month outcomes will become routine ${ }^{20}$.

Data are presented in tables and pictures (Forrest plots). Binary logistic regression was used to assess the prediction values of the independent variables used in the regression model for the decision to stop smoking. These analyses were made separately for 2003 and 2008 to evaluate different prediction patterns. All $\mathrm{P}$ values under 0.05 were considered significant. All analyses were made using StatsDirect version 2.7.8 (www.statsdirect.com).

\section{Results}

A total of 3,229 subjects were included in the survey. Of the participants reached and eligible for participation based on the question when they had last smoked, the response rates were $45.4 \%$ in 2003 and $44.2 \%$ in 2008 . Table 1 shows the prevalence of smoking by age groups and the significant trend of the diminishing number of smokers in all age groups.

We followed the smoking habit in 2003 and in 2008 by monitoring how many non-smokers from 2003 became smokers in 2008, as well as how many smokers from 2003 had quit smoking in 2008. Accordingly, we can speak about the incidences of new smokers and ex-smokers in our sample (Table 2). According to the results of our study, there were $15.3 \%$ new smokers in 2008 compared to 2003 and 133 (26.5\%) of the persons who were smokers in 2003 and had stopped smoking in 2008. Most ex-smokers were older than 65 years of age $(\mathrm{N}=36$, $29.3 \%$ ).
TABLE 1

PREVALENCE OF SMOKING BY AGE GROUPS

\begin{tabular}{lccccc}
\hline \multirow{2}{*}{ Age } & \multicolumn{2}{c}{2003} & & \multicolumn{2}{c}{2008} \\
\cline { 2 - 3 } \cline { 5 - 6 } & Smokers & Non-smokers & & Smokers & Non-smokers \\
\hline$<34(+5)$ & $87(41.2 \%)$ & $44(20.9 \%)$ & & $65(30.8 \%)$ & $52(24.6 \%)$ \\
$35-64(+5)$ & $522(33 \%)$ & $344(21.8 \%)$ & & $473(29.9 \%)$ & $365(23.1 \%)$ \\
$>65(+5)$ & $169(11.8 \%)$ & $300(20.9 \%)$ & & $138(9.6 \%)$ & $335(23.3 \%)$ \\
\hline
\end{tabular}

TABLE 2

INCIDENCE OF SMOKING IN 2008

\begin{tabular}{lccccc}
\hline & \multicolumn{2}{c}{ Non-smokers in 2003 } & & \multicolumn{2}{c}{ Smokers in 2003 } \\
\cline { 2 - 3 } \cline { 5 - 6 } Age & $\begin{array}{c}\text { Non-smokers } \\
\text { in 2008 }\end{array}$ & $\begin{array}{c}\text { Smokers } \\
\text { in 2008 }\end{array}$ & & $\begin{array}{c}\text { Non-smokers } \\
\text { in 2008 }\end{array}$ & $\begin{array}{c}\text { Smokers } \\
\text { in 2008 }\end{array}$ \\
\hline $18-34$ & $18(66.7 \%)$ & $9(33.3 \%)$ & & $20(28.2 \%)$ & $51(71.8 \%)$ \\
$35-64$ & $192(81.4 \%)$ & $44(18.6 \%)$ & & $77(17.5 \%)$ & $364(82.5 \%)$ \\
$65+$ & $189(90.9 \%)$ & $19(9.1 \%)$ & & $36(29.3 \%)$ & $87(70.7 \%)$ \\
Total & $399(84.7 \%)$ & $72(15.3 \%)$ & $133(20.9 \%)$ & $502(79.1 \%)$ \\
\hline
\end{tabular}

The socio-demographic characteristics of the participants are presented in Table 3.

Binary logistic regression was performed to assess the impact of socio-demographic factors on the desire/decision to quit smoking. The criterion variable »do not want to quit smoking « or "want to quit smoking « was used as a dependent variable in the regression model.

Those variables that showed significant bivariant differences and those found to be important from literature reviews were used as predictors in the logistic regression model. The total agreement between the observed and estimated affiliation to a group in 2003 was $69.3 \%$, while in 2008 it was $77.5 \%$. Both models in 2003 and 2008 are statistically significant $(\mathrm{p}<0.05)$ and explain between 30 and $35 \%$ of the total variance of dependent variable prediction.

Figure 1 and 2 show the results of binary logistic regression analysis relating to the smokers' characteristics measured in 2003 and 2008.

In 2003, four predictors significantly contributed to the model or predicted the desire/decision to stop smoking: concern over the adverse effects of tobacco smoking on health, previous attempts to quit smoking, advice obtained in the last year for smoking cessation from physicians and other health workers, and living alone/without a partner.

In 2008, concern about the adverse effects of tobacco smoking on health, previous attempts to quit smoking, advice obtained in the past year to quit smoking by family members and life in rural areas were predictors significantly contributing to the model.

Concern about the harmful effects of tobacco smoking on health was a significant predictor in 2003 and in 2008. Respondents who were somewhat concerned about the 
TABLE 3

THE SOCIO-DEMOGRAPHIC CHARACTERISTICS OF SMOKERS AND NON-SMOKERS IN 2003 AND 2008

\begin{tabular}{|c|c|c|c|c|c|c|c|c|c|}
\hline \multirow{3}{*}{ Variables } & & \multicolumn{4}{|c|}{2003} & \multicolumn{4}{|c|}{2008} \\
\hline & & \multicolumn{2}{|c|}{ Smokers } & \multicolumn{2}{|c|}{ Non-smokers } & \multicolumn{2}{|c|}{ Smokers } & \multicolumn{2}{|c|}{ Non-smokers } \\
\hline & & $\mathrm{N}$ & $(\%)$ & $\mathrm{N}$ & $(\%)$ & $\mathrm{N}$ & $(\%)$ & $\mathrm{N}$ & $(\%)$ \\
\hline \multirow[t]{2}{*}{ Gender } & Male & 310 & 39.8 & 365 & 53.1 & 235 & 34.8 & 361 & 48 \\
\hline & Female & 468 & 60.2 & 323 & 46.9 & 441 & 65.2 & 391 & 52 \\
\hline \multirow[t]{4}{*}{ Education } & $\mathrm{A}$ & 206 & 26.6 & 231 & 33.6 & 165 & 24.7 & 212 & 28.3 \\
\hline & $\mathrm{B}$ & 477 & 61.5 & 344 & 50 & 413 & 61.8 & 404 & 54 \\
\hline & $\mathrm{C}$ & 53 & 6.8 & 57 & 8.3 & 53 & 7.9 & 58 & 7.8 \\
\hline & $\mathrm{D}$ & 40 & 5.2 & 56 & 8.1 & 37 & 5.5 & 74 & 9.9 \\
\hline \multirow{2}{*}{$\begin{array}{l}\text { Marital } \\
\text { status }\end{array}$} & Live with a partner & 534 & 50.7 & 520 & 75.6 & 492 & 72.9 & 563 & 75 \\
\hline & Live alone & 242 & 31.2 & 168 & 24.4 & 183 & 27.1 & 188 & 25 \\
\hline \multirow[t]{2}{*}{ Employed } & Yes & 309 & 40.9 & 192 & 28.6 & 405 & 60 & 514 & 68.3 \\
\hline & No & 447 & 59.1 & 479 & 71.4 & 270 & 40 & 239 & 31.7 \\
\hline \multirow{3}{*}{$\begin{array}{l}\text { Monthly household } \\
\text { income (average) }\end{array}$} & Below & 339 & 43.6 & 280 & 40.7 & 253 & 37.8 & 213 & 28.6 \\
\hline & Average & 353 & 45.4 & 322 & 46.8 & 354 & 52.9 & 434 & 58.3 \\
\hline & Above & 86 & 11.1 & 86 & 12.5 & 62 & 9.3 & 98 & 13.2 \\
\hline \multirow{2}{*}{$\begin{array}{l}\text { Level of } \\
\text { urbanization }\end{array}$} & Urban & 397 & 51.2 & 350 & 50.9 & 447 & 67.5 & 215 & 32.5 \\
\hline & Rural & 379 & 48.8 & 337 & 49.1 & 511 & 68.8 & 232 & 31.2 \\
\hline
\end{tabular}

A - Elementary school and elementary school, B - Secondary school, C - Two-year post secondary school, D - College

harmful effects of tobacco smoking on health were 2.7 times or 3.2 times more likely to decide to quit smoking than those who were not worried at all (OR 2.65, 95\% CI 1.66 to 4.23 vs. OR $3.2,95 \%$ CI 1.84 to 5.59). Serious concern about the harmful effects of tobacco smoking on health was the strongest predictor. Very worried respondents were 18 or 12 times more likely to decide to quit smoking (OR 17.6, 95\% CI 9.41 to 33.17 vs. OR 12.54; $95 \%$ CI 6.0 to 26.2 ) compared to those who were not worried at all.

There was a significantly greater chance that the respondents in both models who had never tried to quit smoking were not going to stop smoking in comparison to those who had tried to quit in the previous month (OR $0.34,95 \%$ CI 0.18 to 0.62 vs. OR $0.09,95 \%$ CI from 0.03 to 0.2 ). While in 2003 an attempt to quit smoking in a previous year was a positive predictor, in 2008 previous attempts at smoking cessation further reduced the desire to try to quit smoking (Graph 1 and 2). In 2003, the participants who received a physician's advice to quit smoking were two times more likely to make a decision about quitting $(\mathrm{OR}=2.00,95 \% \mathrm{CI} 1.18$ to 3.38$)$, while the advice they received from other health workers had a lesser impact on the desire to quit smoking (OR $0.31,95 \%$ CI 0.18 to 0.56 ). Unlike in 2003, in 2008 a significant predictor for the desire to stop smoking was advice for smoking cessation received from family members of the subjects included in this survey (OR=1.71, 95\% CI 1.06 to 2.77). While respondents who were living alone in 2003 were 1.5 times more likely to make a decision on quitting smoking, living without a partner in 2008 was a negative predictor $(\mathrm{OR}=1.49$, vs. 1.03 to 2.17 . $\mathrm{OR}=0.79,0.47$ to 1.31). In 2008 , life in rural areas was a predictor that significantly reduced the desire and decision to quit smoking.

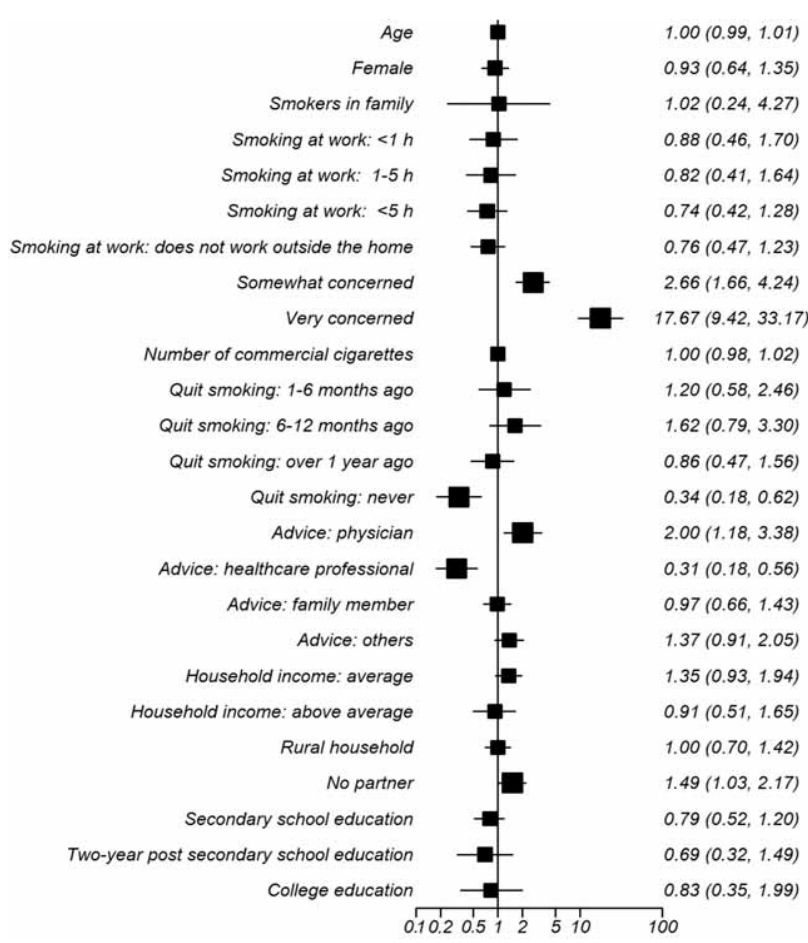

Fig. 1. Results of binary logistic regression in 2003. 


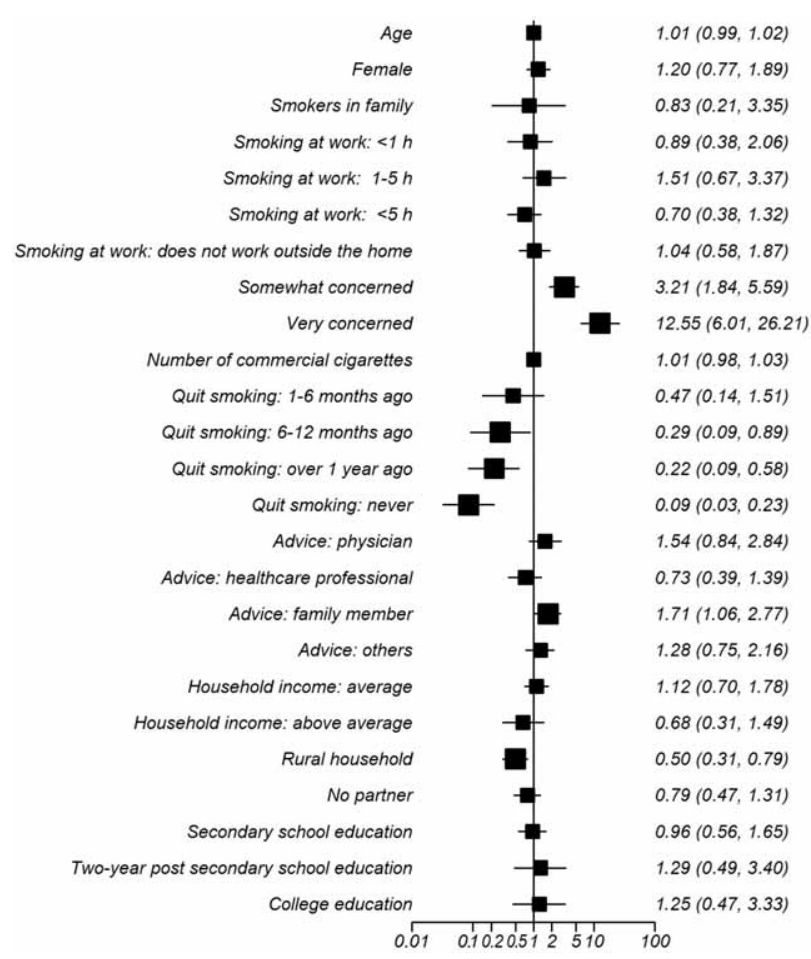

Fig. 2. Results of binary logistic regression in 2008.

\section{Discussion}

The data came from one of the largest Croatian community intervention studies undertaken to track smoking habits among other habits during a five-year period.

By analyzing the collected data, we determined the extent of the smoking epidemic in Croatia in 2003 and 2008 , and investigated the characteristics of smokers in order to obtain insight into the problem. Knowing the characteristics of smokers is important in the development of effective interventions for smoking cessation, particularly when it is known that demographic factors such as gender, age, marital status and monthly income affect whether people try to quit smoking and how successfully they will abstain ${ }^{13,14,21}$. According to our results, in the test sample there were significantly more women smokers, both in 2003 and in 2008. It is thought that a major epidemic of tobacco smoking passes through several stages ${ }^{22,23}$. The tobacco epidemic in various countries is in different stages: the countries from northern Europe are generally in the fourth stage and, according to the results of this study; we might say that Croatia is in the third stage.

In recent years, factors influencing smoking cessation have become the focus of many studies in order to improve the success of smoking cessation therapies ${ }^{11,13,14,21,24-28}$. Caponnetto and Polosa have identified a large number of predictors that can be grouped into three categories: de- mographic and social, psychological and cognitive ${ }^{27}$. In another study, the following variables were identified as predictors for the maintenance of smoking abstinence: monthly income, marital status, living with a partner, number of cigarettes smoked per day, age at the first use of cigarettes and living with other smokers ${ }^{26}$. According to our results, concerns about the harmful effects of tobacco smoking on health contribute significantly to the prediction for the decision to quit smoking. These results are consistent with previous findings ${ }^{11,21}$. There is evidence that previous attempt to quit smoking correlate with the desire to quit ${ }^{11,13,21}$. According to our findings, this was the case in 2003 but in 2008 those smokers who had previously abandoned attempts in the previous year had no desire to try to quit smoking again. This can be explained by assuming that those smokers had lower self esteem due to their prior experience, which was why they did not want to try again, or they were not provided with help during the quitting process. Advice received in the past year for smoking cessation is a significant predictor for the decision to quit smoking. In 2003 it was advice received from a physician, while in 2008 it was advice received from family members. Why physician advice was not a significant predictor for the decision to quit smoking in 2008 should be explored. This may indicate a lack of knowledge among Croatian physicians regarding smoking cessation, as well as their failure to apply appropriate preventive practices. Living alone or being unmarried are well-known risk factors for poor health ${ }^{29,30}$. The results of binary logistic regression in 2003 highlighted this variable as a significant predictor for the desire to quit smoking. Results of binary logistic regression regarding urban-rural differences seem to be complex, indicating that this is likely to be related to the stage of the tobacco epidemic in our country. Both of the above-mentioned results should be further explored.

On a practical level, the findings from this research have both public policy and treatment implications. Our data support the view that for many smokers, tobacco smoking is an addiction and smokers often think about quitting. From the treatment perspective, the data from this study highlight the importance of helping smokers overcome their addiction. Besides the facts that the number of smokers in 2008 decreased in comparison to 2003 and the highest incidence of ex-smokers was in the oldest age group, these are certainly smokers who quit by themselves because there is no organized continuing smoking cessation program in Croatia.

To achieve success in smoking cessation programs, interventions must be accessible, effective and cost-effective. Although there is good evidence for the effectiveness of several existing interventions for smoking cessation, the modern way of life and advances in communication technologies have opened possibilities for the development of innovative interventions for smoking cessati$\mathrm{on}^{31-33}$. Therefore, the findings of this study should encourage our healthcare system to provide effective and modern tobacco-use treatment and follow-up. 


\section{Acknowledgements}

This article was prepared as a part of scientific projects »Regionalism of cardiovascular behavioural risk factors - model of intervention« (108-1080135-0264) and
»Quality of life of physicians and the future medical profession in Croatia" (108-0000000-3577) supported by Ministry of Science, Education and Sport of the Republic of Croatia.

\section{R E F E R E N C E S}

1. DOLL R, J Epidemiol Biostat, 5 (2000) 321 — 2. SCHROEDER SA, N Engl J Med, 347 (2002) 1106. - 3. U.S. DEPARTMENT OF HEALTH AND HUMAN SERVICES. The health consequences of smoking. Nicotine addiction: a report of the Surgeon General; (1988). - 4. TAYLOR DH, JR., HASSELBLAD V, HENLEY SJ, THUN MJ, SLOAN FA, Am J Public Health, 92 (2002) 990. - 5. FIORE MC, Respir Care, 45 (2000) 1196. - 6. WEST R, BMJ, 328 (2004) 338. - 7. EDWARDS R, BMJ, 328 (2004) 217. - 8. DICLEMENTE CC, PROCHASKA JO, FAIRHURST SK, VELICER WF, VELASQUEZ MM, ROSSI JS, J Consult Clin Psychol, 59 (1991) 295. - 9. PROCHASKA JO, DICLEMENTE CC, J Consult Clin Psychol, 51 (1983) 390. - 10. PROCHASKA JO, VELICER WF, Am J Health Promot, 12 (1997) 38. - 11. HAUG S, MEYER C, ULBRICHT S, SCHORR G, RUGE J, RUMPF HJ, JOHN U, Patient Educ Couns, 78 (2010) 57. - 12. ROHRBAUGH MJ, SHOHAM V, DEMPSEY CL, J Drug Issues, 39 (2009) 329. - 13. DERBY CA, LASATER TM, VASS K, GONZALEZ S, CARLETON RA, Am J Prev Med, 10 (1994) 327 - 14. WILCOX NS, PROCHASKA JO, VELICER WF, DICLEMENTE CC, Addict Behav, 10 (1985) 407. - 15. LANCASTER T, STEAD L, Cochrane Database Syst Rev, (2004) CD000165 - 16. FARKAS AJ, GILPIN EA, DISTEFAN JM, PIERCE JP, Tob Control, 8 (1999) 261. — 17. SORSENSEN G, RIGOTTI N, ROSEN A, PINNEY J, PRIBLE R, Am J Public Health, 81 (1991) 202. - 18. LANCASTER T, STEAD LF, Cochrane Database Syst
Rev, (2000) CD001118 - 19. IVIČEVIĆ A Coll Antropol, (2011) - 20. WEST R, HAJEK P, STEAD L, STAPLETON J, Addiction, 100 (2005) 299. - 21. GILPIN E, PIERCE JP, GOODMAN J, BURNS D, SHOPLAND D Tob Control, 1 (1992) 256. - 22. MACKENBACH JP, HUISMAN M, ANDERSEN O, BOPP M, BORGAN JK, BORRELL C, COSTA G, DEBOOSERE P, DONKIN A, GADEYNE S, MINDER C, REGIDOR E, SPADEA T, VALKONEN T, KUNST AE, Eur J Cancer, 40 (2004) 126. - 23. GRAHAM H, Soc Sci Med, 43 (1996) 243. — 24. LEE CW, KAHENDE J, Am J Public Health, 97 (2007) 1503. - 25. HYMOWITZ N, SEXTON M, OCKENE J, GRANDITS G, Prev Med, 20 (1991) 590. - 26. MARINO MG, FUSCONI E, MAGNATTA R, PANA A, MAURICI M, J Environ Public Health, 2010 (2010) 183. - 27. CAPONNETTO P, POLOSA R, Respir Med, 102 (2008) 1182. — 28. MATHENY KB, WEATHERMAN KE, J Clin Psychol, 54 (1998) 223. - 29. OH DL, HECK JE, DRESLER C, ALLWRIGHT S, HAGLUND M, DEL MAZO SS, KRALIKOVA E, STUCKER I, TAMANG E, GRITZ ER, HASHIBE M, BMC Public Health, 10 (2010) 74 - 30. OSLER M, MCGUE M, LUND R, CHRISTENSEN K, Psychosom Med, 70 (2008) 482. - 31. LANCASTER T, STEAD L, SILAGY C, SOWDEN A, BMJ, 321 (2000) 355 - 32. CIVLJAK M, SHEIKH A, STEAD LF, CAR J, Cochrane Database Syst Rev, (2010) CD007078. - 33. WHITTAKER R, BORLAND R, BULLEN C, LIN RB, MCROBBIE H, RODGERS A, Cochrane Database Syst Rev, (2009) CD006611.

M. Čivljak

University of Zagreb, School of Medicine, »A. Štampar « School of Public Health, Rockefeller st. 4, 10000 Zagreb, Croatia e-mail: mcivljak@snz.hr

\section{PREDIKTORI ŽELJE/ODLUKE ZA PRESTANAK PUŠENJA U KOHORTI ODRASLIH HRVATSKIH PUŠAČA PRAĆENIH U PETOGODIŠNJEM RAZDOBLJU: CroHort STUDIJA}

\section{S A Ž E T A K}

Rad daje pregled o incidenciji pušenja i sociodemografskim obilježjima hrvatskih pušača u petogodišnjem razdoblju, te procjenjuje prediktore želje/odluke za prestanak pušenja. Ukupno je bilo uključeno 3229 ispitanika. Prema našim rezultatima postoji značajan trend smanjenja broja pušača u svim dobnim skupinama u 2008. u odnosu na 2003. godinu. Gotovo polovina pušača uključenih u istraživanje izrazila je želju za prestankom pušenja. Čimbenici koji značajno doprinose predikciji za želju/odluku o prestanku pušenja bili su različiti u 2003. i 2008. godini, osim jednog. Zabrinutost zbog štetnih posljedica pušenja duhana na zdravlje značajan je prediktor u oba modela. Jaka zabrinutost zbog štetnih posljedica pušenja duhana na zdravlje najjači je prediktor. Vrlo zabrinuti ispitanici imaju veće izglede da donesu odluku za prestanak pušenja (OR 17,6; 95\% CI 9,41-33,17 vs. OR 12,54; 95\% CI 6,0-26,2). 